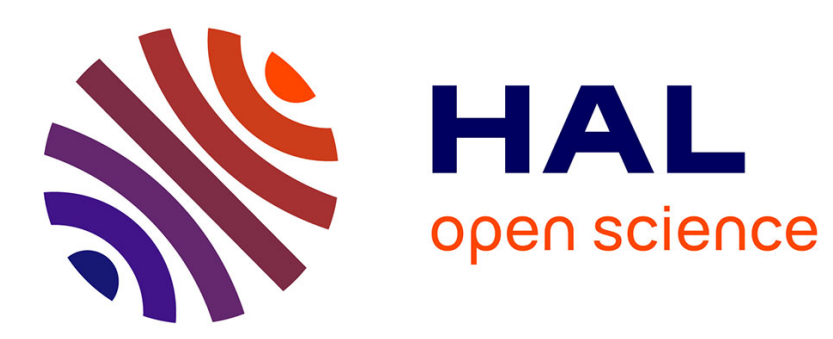

\title{
ENVIRONMENTAL TECHNOLOGICAL CHANGE AND GOVERNANCE IN SUSTAINABLE DEVELOPMENT POLICY
}

Sylvie Faucheux, Isabelle Nicolaï

\section{- To cite this version:}

Sylvie Faucheux, Isabelle Nicolaï. ENVIRONMENTAL TECHNOLOGICAL CHANGE AND GOVERNANCE IN SUSTAINABLE DEVELOPMENT POLICY. Ecological Economics, 1998, 27 (3), pp.243-256. 10.1016/S0921-8009(97)00176-6 . hal-01799267

\section{HAL Id: hal-01799267 \\ https://hal.science/hal-01799267}

Submitted on 24 May 2018

HAL is a multi-disciplinary open access archive for the deposit and dissemination of scientific research documents, whether they are published or not. The documents may come from teaching and research institutions in France or abroad, or from public or private research centers.
L'archive ouverte pluridisciplinaire HAL, est destinée au dépôt et à la diffusion de documents scientifiques de niveau recherche, publiés ou non, émanant des établissements d'enseignement et de recherche français ou étrangers, des laboratoires publics ou privés. 


\title{
ENVIRONMENTAL TECHNOLOGICAL CHANGE AND GOVERNANCE IN SUSTAINABLE DEVELOPMENT POLICY
}

\author{
Sylvie Faucheux and Isabelle Nicolaï \\ Centre d'Economie et d'Ethique pour l'Environnement et le Développement \\ C3ED, Université de Versailles-Saint Quentin en Yvelines \\ 47 boulevard Vauban, 78280 Guyancourt, France \\ Tel : + 33139255375 Fax : +33139255300 \\ Email : Sylvie.Faucheux@ c3ed.uvsq.fr
}

\begin{abstract}
:
\end{abstract}
Key words:

\section{INTRODUCTION}

Avec le concept de sustainable development, il ne s'agit plus de tenir compte d'une contrainte supplémentaire à la croissance économique de nature environnementale, comme cela avait été le cas dans les années 1970 avec la croissance zéro préconisée par le Club de Rome. Indeed sustainable development aims at reconciling the pursuit of goals traditionally associated with economic growth (such as material wealth and consumer satisfaction), with ecological protection. Ce nouveau projet de société a été affirmé lors du Sommet de la Terre à Rio en 1992 et repris un an plus tard par le Cinquième programme d'Action de la Commision Européenne, ayant pour intitulé Towards Sustainability. A related evolution has taken place in the private sector. Firms are increasingly considering to take the environment into account not just as an exogeneously imposed cost or constraint, but as a strategic opportunity. On parle désormais de stratégie "win-win" pour qualifier les stratégies des firmes permettant d'accroître ou de préserver la compétitivité, tout en répondant de façon positive aux problèmes de qualité environnementale (Porter and Van der Linde, 1995). La nécessité qui prévalait encore dans les années 1980, se serait convertie en vertu dans les années 1990.

However, it cannot simply be assumed that these simultaneous changes in public attitudes, business policies and government regulations are going to guarantee the conditions for long-term ecological, social and economic sustainable development (Palmer, Oates and Portney, 1995). We must look with as open mind at the prospects for reconciling economic competitiveness with the priority of environmental protection and of social justice so as to achieve a "win-win" result on macro-economic and not merely micro-economic scale. Many debates about the compatibility between sustainable development and competitiveness, hinge on views about the extent to which technological change is thought to have the potential to reduce pollutant emissions and improve efficiency of natural resource, land and water use. If products, manufacturing processes and services are to be made significantly less intensive and much more dematerialised from an environmental viewpoint over the coming ten years, technological progress must play a fundamental role, though change in consumption patterns should also be taken into account (Ropke 1996). Therefore, major business corporations and alliances are in a position to influence the direction taken by environmental technological innovations. De même, s'il est devenu courant de préconiser le "Principe de Précaution" pour les décisions comportant des risques environnementaux, il n'empêche que son application s'apparente souvent à un gel quasiirréversible des positions concurentielles en matière technologique acquises au moment de la décision. Cette situation peut favoriser des comportements stratégiques de la part des différents acteurs, en l'occurence des firmes, afin d'orienter la décision finale dans le sens de leur intérêt. 
Therefore we must take into account the important roles of "governance" ${ }^{1}$ defining wider social responsabilities (at the local, national and international levels) in the search for firm "win-win" strategies combining business competitiveness, social cohesiveness and improved environmental performance.

In this context, we adopt an evolutionnary perspective of technological change and we deepen the endogeneous character of this last one in the possible industrial dynamics of transition to sustainable development. In section 1, we explain the importance that environmental technological innovation can at times play in the search for a competitive edge and in the implementation of a sustainable development. In section 2, we discuss the fundamental roles that firm's strategies vis-à-vis the endogeneisation of technological change. Some case studies are presented of on going structural change in the organisation of firms and of markets to operationalise the implementation of environmental technological innovations by firms susceptible to develop "win-win" strategies. In section 3, we show that allowing competitition among firms to become the only factor determining "win-win" strategies could lead to "locked" technological and social options being chosen which do not contribute to overal goals of ecological, social and economic sustainability. This is why we introduce, as complements to competitiveness, other notions such as the public interest and collective responsability for the future. We propose in this way a "satisfycing democratic decision-making framework" to implement sustainable development policy .

\section{TECHNOLOGICAL CHANGE, SUSTAINABLE DEVELOPMENT AND INDUSTRIAL COMPETITIVENESS}

We recall in this part the complex relationships between the triad technological change, sustainable development and industrial competitiveness (Faucheux, 1997; Skea, 1994). We review the major role of technological change in the implementation of "win-win" strategies and we introduce the evolutionary approach to technological change, placing emphasis on notions of strategy.

\subsection{Environmental Technological innovation : a major role for the implementation of "win-win" strategies}

New forms of competitiveness are dynamic and increasingly international in nature. By dynamic, we mean that a competitive advantage is not dependent only on existing cost and price considerations (or, more generally, on the ability to perform within a given set of restrictions), but rather on the ability to innovate and bring about technological change so as to shift or even eliminate existing constraints. A dynamic competitive process is thus characterised by changes in technological as well as marketing opportunities. Le changement technologique environnemental a un rôle clé dans cette nouvelle dynamique de la compétitivité internationale. Plusieurs secteurs industriels ont connu, depuis un peu plus d'une décennie, de véritables compétitions technologiques induites par la révélation d'un problème environnemental. L'industrie chimique (rôle des CFC dans la destruction de la couche d'ozone, controverse sur les phosphates dans les lessives) ou encore l'industrie automobile (pot catalytique versus moteur propre dans les pluies acides) ont été particulièrement concernées. According to studies made by the Japanese government (MITI), some 40 percent of the world's production of goods and services over the first half of the twenty-first century may be from environment or energy-linked products and technologies (MITI 1988, Miller and Moore 1994). Dans cette perspective, la prise en compte de la dimension écologique devient un facteur fondamental dans la sélection et la diffusion des technologies en concurrence. Moreover,

\footnotetext{
${ }^{1}$ Some authors use the term "governance", par opposition à "governement" pour désigner "la totalité des différents moyens par lesquels les individus et les institutions, publiques et privées, gèrent leurs affaires communs. Il vise aussi bien des institutions et des règimes officiles dotés de compétences d'exécution, que des arrangements amiables que les citoyens et les institutions estiments, d'un commun accord ou intuitivement de passer" (European Commission, 1995, p 2).
} 
technological change is not, in this context, considered as an exogenous variable of an unknown nature. On the contrary, innovation potential is seen as closely related to political choices, social conditions and economic institutions.

Par ailleurs, la conception que l'on peut avoir des potentialités du changement technologique à l'égard de l'environnement détermine la vision de la soutenabilité et la façon de l'atteindre. Studies adopting the weak sustainability perspective extend the conclusions of neoclassical growth and capital theories to natural resources (Faucheux, Muir, O'Connor 1997). While the models are fairly disparate in their details, in general a definition of conditions is sought under which per capita consumption does not decrease. This preoccupation remains more or less in line with the results produced by Stiglitz's (1974) pioneering model. In brief, a constant per capita consumption path can be permanently maintained as long as the positive effects of substitution and technological innovation outweigh the exhaustion of natural resources, of population growth and of discount rate. In this perspective, sustainability is often assured by assuming the existence of a "back-stop technology" (Nordhaus 1992) or by assumptions about improvements in factor productivity (high elasticities of substituability and/or improved average productivity through time).

Conversely, those adopting the strong sustainability approach are pessimistic about the beneficial effects of the impacts of technological change. For Daly (1991), for example, technological change can at best delay, but not prevent, the need for a transition to an ecologically limited stationary state. The reasoning given for this inevitability is the absolute nature of the ecological constraints imposed by the second law of thermodynamics, which precludes indefinite productivity improvements and substitutability. Cette conception, qui prône la dématérialisation de l'économie, connaît un relais politique important dans des pays comme l'Allemagne, les Pays Bas, la Suisse et ceux du Nord de l'Europe (Haake and Hinterberger, 1997).

In both cases, the rate of technical change and production levels in key sectors can be indicators of success or not in the implementation of sustainability policies. However, neither of the above perspectives offers the basis for an in-depth analysis of the real processes of technological change. The main reason for this common limitation can be seen in the similarity of the conception of economic production and of technological change in the two approaches. Indeed, the question of production is reduced, at the aggregate level, to a problem of growth (or non-growth); and technological change is correspondingly reduced to a single dimension, a rate whose maximum is presumed to be exogeneously determined. The divergence between the two schools then concerns the value of this rate. This means that neither party is able to incorporate the multidimensional nature of environmental technological change, bearing in qualitatively different ways on (interalia) prospects for economic production, natural resource availability, waste production, mitigation or augmentation of the adverse impacts of pollution, species viability, ecosystem conservation and biosphere life support functions.

\subsection{Towards an endogeneisation of environmental technical change for a "win-win" strategy analysis}

We therefore suggest that policy oriented analysis of prospects for what we call "win-win" strategies requires a more sophisticated representation of the interactions between the productive system with its changing environment (O'Connor, 1994a, 1994b). This paper takes it as self-evident that one of the major stimuli to economic and technical change is changed social perceptions (including accumulating scientific evidence and hypotheses) about ecological and health impacts of economic activity. The question we pose is how these social perceptions come to be reflected in choices at firm and industry level ? To frame our answer, we can appraise two approaches to the analysis of technical change as an endogeneous processes and its roles in relation to sustainability : endogeneous growth theory and evolutionary theories of technological change. The first one belongs to Neoclassical approach whereas the second one is a lot closer to Ecological-Economic perspective (Faucheux, Noël 1995; Norgaard 1994). 
Recognition of the limitation of standard neoclassical growth theory has naturally triggered interest in possibilities of further developments in the growth theories that might give more clarity on the way of evaluating the contribution of technical progress to sustainable development (Gastaldo \& Ragot, 1996). Yet the resulting endogeneous growth models tend only to offer a theoretical account of the origins of the technical progress (such as apprenticeship phenomena, human capital) rather than any estimate of its actual or possible future rate (Benhaïm, Schembri 1996). In these models the sources of technical change are ultimately reduced to economic type variables (appropriability, patents, educational expenditure and so on). This means that the endogeneisation is achieved by the reduction of technical change to purely economic phenomena. There is an inherent presumption that all the coordination problems will be solved in the long run-and thus that the equilibrium concept has explanatory pertinence. This treatment does not take into account the problems connected with transition dynamics and in effect assumes that the technological change is automatically "assimilated" by the economic system and the social collectivity. The endogeneous growth models, incorporating or not natural capital, remain first and foremost equilibrium models which are ill-equiped to take into account the complex nature of technological change and the discontinuities in time and perception that it implies. This is why these models are limited in their analysis of sustainable development (Beckenbach, 1998).

Evolutionary perspective of technical change gives a central place to processes of disequilibrium in which the concept of transition and properties of non linearity have important roles to play (Amendola, Froeschlé, Gaffard and Lega, 1996). It concentrates on observing economic, institutional and ecological realities without trying to find a normative reference situation such as an equilibrium. The presumption is that an understanding of the workings of technological path selection and the nature of technological societal economic interrelations can be gleaned only when technical elements are represented as a complex dynamic system (Saviotti 1986). This has the advantage of allowing representation of the essential role that technology change choices unfolding over time will have in possible "transition paths" for sustainable development. It further suggests the importance of economic policy for "steering" the economic system in the cumulative process of change. The approach looks more at conflicting relations and their development over time (the role of strategy in different forms), whereas most of the other analyses nullified conflicts by using optimisation. The focus is placed on strategy as response to uncertain and changeable circumstances, on the degrees of freedom that actors possess on the constraints that they face, but also the freedom of movement that they may have and the range of opportunities that they may identify, and over time, create. In this perspective the analysis of the environmental firms strategy is central in the way firms are interest players on the "endogenisation" of technical change.

\subsection{A dynamic perspective of environmental technological change}

Toute innovation technologique environnementale est-elle en mesure d'impulser une nouvelle dynamique industrielle vers une trajectoire de développement soutenable ? To answer to this question, it is useful to remind the following distinction (Frosh, 1995; Malaman, 1998) :

(i) Add-on, or end-of-process technology, is any modification made ex post to a production or machine use process that alters its environmental performance. It frequently consists of incremental changes to existing technology, that include processes and products for waste separation, storage and disposal, such as incinerating techniques for industrial waste or systems for cleaning up contaminated soil. Although these techniques do not prevent the creation of polluting substances, they have been useful during the past 20 years for reducing the impact of the toxic substances through controlling the final destination and form of the emissions. One problem is that such measures frequently shift the environmental problem from one place to another (e.g. toxic solid wastes rather than toxic smoke) instead of eliminating it. 
(ii) Integrated technologies, also referred to as clean technologies (Duchin, Lange and Kell 1995), are new production or service methods whose whole conception is to reduce environmental harm. Rather than, for example, capturing polluting substances after they have been produced (as with the end-of-process technologies), the goal is not to produce the harmful susbtance at all, or to produce less of it, or a less harmful one. Here, the consideration of environmental issues has the potential for acting as a push factor in technological change for the entire productive chain associated with a product. This allows the prioritising, if desired, of specific environmental performance criteria such as the availability of inputs over time or environmental impacts at the various stage of a product's lifecycle. Therefore European car manufacturers, already incorporate from the design stage onward, various criteria having to do with the end of the useful life of vehicles, through, for example, substitution mechanisms between new and regenerated raw materials. The technical espects of the manufacturing process can also be affected, leading to an alteration of existing techniques (addition of technology, equipment alterations) or to the development of new processes. This can give rise, for example, to a re-examination of technical aspects having to do with the assembly stage, in light of the new notion of "disassembly". Xerox, for example, has become a leader in component products which can be disassembled. Canon has innovated by inventing recyclable reusable cartridges. The competitive advantage of the innovation gives access to, or creates, a specific market segment (Shrivastava, 1995).

Only the environmental technological innovations belonging to this second category can be considered to be of the "natural capital augmenting" type. They improve the productivity of natural resources or makes it possible to reduce the adverse effects of pollution and waste corresponding to a given level of production of goods and services. Dans ces conditions, seules ces technologies sont en mesure de susciter un changement structurel écologique permettant a delinking entre la croissance économique et les facteurs nuisibles à l'environnement. In other words, only integrated technologies can generate a new impulse to innovation in favour of genuinely sustainable development. However, another distinction may usefully be introduced, between "incremental" and "radical" innovations, which introduces the issue of the dynamics of technology (acceptance, penetration, saturation, etc) over an extended period. This distinction does not apply exclusively to environmental technology, but rather comes from evolutionary theory of technology change.

Most environmental technology innovations, whether add-on or integrated, belong to the category of incremental innovation because they are improvements to products or manufacturing techniques occuring continuously throughout the history of the class of technology. Few of them are radical innovations which cause breaks in the continuity of evolving processes or products, leading to the transformation of methods of production or distribution (Freeman, 1982). Chlorine-free chemical processes, organic fuels and photovoltaic energy generation would fall into the category of radical innovations answering to environmental problems. Ce sont de telles ruptures technologiques qui sont à même de pouvoir modifier profondément economy-wide production, consumption and lifestyles, en amorçant une nouvelle trajectoire technologique qui coïncide avec une trajectoire de développement soutenable.

De telles distinctions posent alors le dilemme entre le court et le long terme. Le développement de technologies intégrées radicales peut prendre du temps (for example, environmental applications of synthetic chemicals, new materials, biotechnology, etc...). Or, il souvent indispensable d'agir à court terme sous la pression de l'opinion publique ou des révélations scientifiques. Ainsi, les firmes, sous ou sans la pression des pouvoirs publics, sont-elles amenées à favoriser l'adoption de technologies intégrées incrémentales, voire de technologies de bout de chaîne, parce qu'elles sont immédiatement disponibles. Une telle décision peut alors piéger le système dans une solution contraire aux objectifs de développement soutenable et empêcher les firmes d'opter pour des stratégies permettant de s'engager vers les innovations adéquates. Ces diverses catégories de technologies environnementales doivent alors être développées de façon complémentaire sur un échélonnement temporelle suffisamment flexible pour amoindrir les problèmes (économiques, sociaux et écologiques), parfois irréversibles, de transition, voire les dommages irréversibles liés aux objectifs de développement soutenable. Ainsi, le Japon, 
conscient de cet enjeu, a t-il développé, depuis les années 1970, un "portefeuille" de technologies environnementales afin d'assurer, non seulement une importante flexibilité stratégique face aux problèmes environnementaux toujours plus incertains, mais aussi une compétitivité sur le moyen et le long terme où certaines de ces innovations technologiques environnementales vont avoir un rôle crucial (Faucheux, Nicolaï, O'Connor, 1997).

\section{Firms as stakeholders in the endogenisation of technological change}

Firms are involved daily and through long term strategic decisions, with implementation of new environmental technologies. We explain the different kinds of firm's strategies vis-à-vis the environmental technological change for giving effect to sustainability. This raises the question of what sorts of changes in industrial organisation firms developing "win-win" strategies can be implemented to promote environmental technological innovation.

\subsection{A typology of business strategies on the environmental innovation}

Strategies implemented by firms with respect to the environment largely determine the kinds of the environmental technological innovation adopted. These strategies can be classified in the three following categories which are not independant. Indeed a firm can pursue a double or a triple strategy in function of the type of environmental problem.

(i) The defensive environmental strategy was dominant in many pollutant industries up to the eighties. According to a study by the European Commision's DG III (1995), firms most likely to engage in defensive strategies in Europe are major companies that are leaders in their field at home and, to a lesser extent, small and medium sized firms. The sectors where this typically occurs are the machine, textile, food-processing, wood and paper, automobile and metallurgical industries. Within the EU, this tendency was particularly pronounced for some of the Mediterranean countries. Cette attitude relève de la stratégie de domination par les coûts (Porter, 1990). The damages done to the environment through production and consumption activity are viewed statically as "negative externalities" which mean there is a socially inefficient allocation of economic resources. The public policy objective then is to "internalise" this negative impact by, for example, a tax on pollution or a requirement to introduce more expensive "cleaner" technology (which will often be, in the best case, an incremental innovation). In the point of view of pollutant firms, those mechanisms amount to an increase in the costs that polluting firms would have to meet.

There exists different kinds of defensive strategies. First of all, firms may refrain from reporting their pollution-causing activities or from cutting back on the pollution they cause, simply in order to avoid the costs of such measures. They can also bypass or block regulations. For example, Atochem, France's only manufacturer of CFCs, after opposing regulations on CFC gases, tried to find ways, following the adoption of the Montreal Protocol, of using regulations to its advantage. The moratium given to developing countries and Eastern Europe opened the way to the construction of new manufacturing facilities for CFC 11 and 12 in Tunisia. Firms may also engage in transfers of production or in dumping practices to export markets where the safety or environmental regulations are non-existent or not enforced. An example involves some Western cement corporations, which have started operating subsidiaries in countries where regulations were virtually non-existent (Latin America) or where controls existed but were lightly enforced, such as Turkey, Poland and Hungary (Gramond, Setbon 1996).

(ii) The follower strategy regarding the environment.. A follower is a firm that does not make the running with new innovations or lobbying for regulatory change, but adjusts purposefully to the new ground rules. Such behaviour can be motivated for a variety reasons, as on grounds of legitimacy, in order to try to avoid future accusations, or to secure future markets, or else simply to avoid being a loser in tomorrow's competitive race. The case of European cement manufacturers can be cited again. 
Despite a generally defensive approach to regulations concerning their main business, they have grasped at one significant advantage which could be gained from environmental controls. This is to develop their very minor side-business of waste disposal for industrial liquids and solids with a high and low energy content, such as hydrocarbon sludge, tar, pitch, solvents, varnish, distillation residues, spent oils, tyres, residue from automobile-body crushing (Setbon, 1997). According to a survey of firms made by the European Commission (DG-III, 1995), il apparaît que même si beaucoup de firmes entreprennent des actions en réponse aux régulations environnementales, leur principale motivation, quel que soit le secteur d'appartenance est de satisfaire aux exigences de la réglementation, sans plus. The main reason for this seems to be that environmental performance is usually perceived (especially by small companies) as a problem of compliance associated with nonproductive expenditures.

(iii) Proactive and integrating strategies of firms towards the environment. :Some highly publicised accidents such as the Seveso toxic could release in Italy (De Marchi 1997) and the Bhopal disaster in India, have changed public and regulatory opinion so that firms must now take a more proactive position. A growing number of polluting firms have begun to consider environmental protection as not just a constraint but as providing a potential competitive edge, owing to their competitive situation and falling margins as well as to the increase in consumer awareness of the ecology. Since the 1980s, the world has witnessed the development of what Porter (1990) refers to as the new competitiveness paradigm based on a dynamic vision which is to the base of the evolutionist approach of technological change which we have defined previously. According to this view, competitiveness at the industry level may well be achieved through higher productivity or lower prices, but also by the ability to provide different and better-quality products priced higher than the others. Armed with this new concept of competitiveness, many firms take the view that, rather than maximising profits within a fixed set of environmental constraints, it is better to modify these constraints in order to gain a competitive advantage. The environment introduces a new criterion for differentiating among products extending to the development of environmental standards or labels (ISO 14000 at the international level). There is new emphasis on "green" properties of products, such as their useful life or their price-to-weight ratio. De même, l'environnement peut susciter la découverte et l'organisation de débouchés pour certains flux résultant du processus de production. A travers cette organisation technique, des matériaux réduits au préalable au statut de déchets, deviennent des sous-produits valorisables. Leading European automobile manufacturers, for example, have been looking for a way to compute a recyclability index that could be used for business purposes. Concerns about the disposal of old vehicles have also given rise to discussions concerning the useful life of cars. On peut aussi donner le célèbre exemple du parc écoindustriel de Kalundborg au Danemark, nommé Symbiosis, regroupant plusieurs entreprises (une centale électrique, une raffinerie de pétrole, une usine pharmaceutique, une usine d'industrie synthétique, un producteur d'acide sulfurique, une cimenterie, plusieurs agriculteurs et un réseau de chauffage) qui ont établi un système d'échanges où les déchets industriels des unes sont utilisés comme inputs des autres.

Firm, by developing a proactive strategy, does not limit its business exclusively to already existing market segments but also seeks to influence changes in consumer perceptions and demand (product differenciation, acceptance, changes in behaviour, etc...). Certaines PME peuvent développer un positionnement priritairement environnemental de leurs produits pour obtenir un avantage compétitif et devenir leader dans cette niche stratégique. Body Shop a, par exemple, véritablement créé une "niche verte" dans l'industrie des cosmétiques qui était dominée par les grands groupes chimiques mondiaux.

However, proactive strategy is particularly evident among many large multinational corporations in the industries, especially those that see themselves threatened by environmental controls--namely electrical utilities, chemical firms, oil refineries and water-treatment plants (DG III, 1995). The famous example of Du Pont can be cited. Anticipating that regulations on CFCs were unavoidable, the company, one of the world's leading chemical firms and the largest manufacturer of 
CFC, had been conducting research into CFC substitutes since 1975 to have an advantage in the distribution and manufacturing of those substitutes when the moment was right.

Au total, les firmes adoptant une stratégie environnementale pro-active visent à réconcilier des considérations commerciales avec les besoins de responsabilité sociale et sont donc celles susceptibles de favoriser une véritable stratégie de type "win-win" et les innovations technologiques environnementales.

\subsection{The organisational and market structures for win-win strategies}

Such win-win strategies require adequate organisational and market structures. A simple way to discuss organisational change of firms is in terms of the structure of the market (S), the behaviour of firms (B) and performance (P), as proposed by Bain (1956). These three elements can be seen as interactive over time. For example, a firm's profitability, market share or environmental performance has an impact on its subsequent strategies (or behaviour), which can contribute to modifying market structures. Du Pont Corporation, for example, adopted early on a particular research strategy (behaviour) when it elected to emphasise research into CFC substitutes. Subsequently, a strong negotiating activity (in support of regulations on the reduction of CFC emissions) enabled Du Pont to improve its performance by securing a competitive edge in the new market conditions and structures that changed to its advantage.

Changes in the market structure generally go hand-in-hand with changes in a firm's internal organisation. Aoki $(1986,1990)$ studied respective performance of different systems according to the nature of technological innovation. He compared the relative efficiency of two coordination modes (vertical and horizontal structures) faced to specific problems of innovation which are complexity, irreversibility and unpredictability. He puts ahead two sets of coherent relationships between internal organisation and market structure : one dominated by internal uncertainty when firm environment is stable; another one characterised by an internal coordination of environment changes. The development of environmental technology requires the creation and exploitation of new routines in a strong uncertainty. Then, the implementation of such environmental innovation enforces the ensuring of internal coordination. Chandler (1977) has outlined the importance of technology and the evolution of production process (including energy resources) in determination of firm organisational forms. In fact consideration of environmental issues can occur at several levels. It can involve the creation of a specialised field with its own structures, the addition of an extra variable to an organisational chart or the implementation of environment-specific concepts throughout management. In-house discussions can result in the creation of new departments (environment division, recycling division, etc.) and cause the inclusion of an additional decision criteria. This adaptation of internal structure is particularly visible in the chemical industry. Rhône-Poulenc, ICI, Bayer, Union Carbide and Ciba, for instance, have added special "environment" horizontal divisions (ICI elaborates matrix management around environmental innovation) and, at the same time, created incentives (e.g. the Proforis employeemotivation programme, or PRISE) to ensure that activities are horizontally co-ordinated.

Environmental technology innovation can, equally, provoke external organisational changes, such as new co-operation among firms en vue d'économie d'échelle et de partage des risques en matière de R\&D. The environment here becomes a factor in the evolution of relationships between firms and others they do business with, either vertically (as in the case of industries and business contacts upstream or downstream from production), or else horizontally (companies in the same sector). For example, changes in relations with "upstream" participants in the system (subcontractors and suppliers) provide a vivid example of this, bringing about stronger links and demands for evidence of the environmental quality of goods. Many factors are contributing to this, including the certification procedures required of suppliers in certain instances. In the european automobile industry, for example, the fact that manufacturers are taking into consideration the disposal of scrapped vehicles has had repercussions for all firms operating upstream, whether they are parts suppliers or processors 
and chemical companies supplying raw materials. Business links are developing between manufacturers and suppliers, in connection with the development of recycling systems or of designs that take into account disposal problems, as well as between the various suppliers of automobile manufacturers (as in the case of the invention of Valcor in 1991). Giving consideration to the environment and in particular to the disposal of used products has also resulted in the development of a new set of interconnections between firms operating downstream from manufacturers. In the case of the european automobile sector, it has resulted in joint operations being set up by manufacturers and downstream companies to develop recycling systems. For example, a joint project by PSA, Compagnie Française des Ferrailles (CFF) and the Vicat cement company resulted in the creation of a facility for pre-industrial applications at Saint-Pierre de Chandieu in France (Chailloux 1996).

More generally, given the unpredictability of environmental developments and the importance of capital outlays for environmental protection, alliances strategies are particularly attractive for firms pursuing a proactive environmental strategy. The different categories of these alliances can be derived from examples taken from various industries and countries.

(i) Co-operation agreements for the development of new processes. France's Rhône-Poulenc and Sweden's Kenura set up a jointly-owned subsidiary in 1990 to look for more efficient and cheaper ways of fighting water pollution. There are also co-operation agreements between European cement makers and parts manufacturers, for the development of new processes and to conduct basic research into combustion and flame control.

(ii) Co-operation agreements for the development of new products. Siemens and Bayer have developed catalytic converters for the denitrification of flue gases in order to lower nitrogen oxide emissions. Elbo, the public authority operating the Athens bus system, and Rhône-Poulenc have designed a catalytic converter for diesel engines which cuts back on exhaust fumes.

(iii) Co-operation agreements for the recycling of packaging and products. Eco-emballages is a company founded in 1992 in France by a group of packaging firms and manufacturers and distributors of packaging materials. In the european automobile industry, the issue of scrapping vehicles has been the object of several agreements involving either just manufacturers or other industry firms as well. Agreements on the development of a recycling network have been signed, such as the 1994 pact between Renault, BMW and Fiat, which Rover later joined. Research agreements have in addition been signed by French manufacturers and some of their competitors (the 1995 agreement between Renault and Mercedes-Benz).

(4) Mergers and acquisitions. This type of strategy can be justified by a desire on the part of firms to focus on their core business and to reduce risk exposure and the cost of implementing environmental technology innovation. Rhône-Poulenc and Sita have acquired, through their jointlyowned subsidiary TERIS, the business of SCORI, a company specialising in the disposal of waste with cement makers.

All of these strategic alliances are built along the principle of quasi-integration (Aoki, 1986). This process leads, typically, either to more concentration or to the creation of network entities or networks of firms. These alliances and mergers by firms alter the balance of power, and in the process of organisational changes it is easy to foresee the disappearance of certain market participants. In certain instances, this leads to a loss of local control (or of national economic sovereignty), and can lead to more concentration within a sector or domain of activity, and more generally to accentuate the phenomenon of economic globalisation.

\section{Sustainable development as a social partnership between firms, citizens and government.}


According to the previous section, we can note that the apparently beneficial role of firms towards sustainability emerges contingently, out of new challenges for commercial viability. C'est pourquoi, à côté de la compétitivité, nous introduisons d'autres notions comme la responsabilité collective vis-à-vis des générations futures et les esquisses de gouvernance adéquates.

\subsection{Social and environmental tensions in relation to "win-win" strategies of firms}

Certaines stratégies a priori de type "win-win" peuvent paraître fructueuses en termes de compétitivité et de préservation de l'environnement sur le court terme, tout en encourageant les firmes et l'ensemble de l'économie à développer des trajectoires technologiques "vérouillées" qui, sur le long terme, s'avèrent sous-optimales et en dehors des sentiers de soutenabilité. Mention here can be made of the well publicised replacement by McDonald's of a white polyethylene packaging sheet with polystyrene foam, which makes no significant difference from an environmental point of view -- it is a matter of air pollution versus water pollution (Duchin, Lange, Kell 1995). De même, in the phosphate-free detergents polemic, Henkel a constitué un "lock-in" technologique sur les lessives sans phosphate. Ce "vérouillage" issu d'un état de monopole technologique provient ici de l'existence de rendements croissants (increasing returns) d'adoption. Indeed, manufacturers came out with phosphate-free laundry detergents not because it had been ascertained that they were safer than traditional products, but because every time one company brought out a phosphate-free detergent, the probability rose that another company would do likewise. Or, le débat sur la pertinence écologique des lessives sans phosphate est toujours ouvert (Moreau, 1994)! Dans l'affaire du pot catalytique, l'origine du "lock-in" est cette fois d'ordre institutionnelle, dans la mesure où la Commission Européenne, poussée par certains groupes de pressions, n'a pas laissé le temps nécessaire au développement d'une technologie alternative véritablement fiable. Or, on a depuis constaté que le pot catalytique nuit à l'efficacité énergétique et a retardé l'élimination du protoxyde de plomb dans les moteurs. Au travers ces exemples, il apparaît que les évènements initiaux, amplifiés par l'opportunisme de certains acteurs industriels, risquent de déboucher sur des choix irréversibles qui, bien que commercialement viables et satisfaisants pour le consommateur dans le court terme, se révèlent finalement contradictoires avec les objectifs de soutenabilité.

Plus généralement certains craignent que le mouvement en faveur de la dérégulation aux niveaux national ou international, conduisent à ce que les rênes de la protection environnementale échappent des mains des instances politiques au profit des instances professionnelles privées ou de grands groupes industriels. Ainsi un processus "d'autoréglementation" industriel, en d'autres termes d'engagement unilatéral de l'industrie. Nous pouvons citer les exemples suivants : l'Engagement de Progrès de la chimie française en 1990, l'engagement de l'industrie allemande sur la réduction des émissions de CO2, en 1995, ou encore le code de bonne conduite de l'industrie minière ICME (International Council for Metals and the Environment), chartre signée par 27 entreprises minières multinationales. Ce type d'engagement unilatéral qui n'est signé par aucune autorité publique s'esquisse en tant que variante libérale de ce qui est désormais courant de qualifier d'engagements volontaires (Borkey, Glachand, 1997). Or, l'efficacité environnementale et sociale de ces derniers est sujette à discussion. Le rôle central des firmes dans l'élaboration de ces outils de politique environnementale peut amener à une distorsion de la décision au détriment de l'intérêt général (phénomènes de capture réglementaire). Un cas de capture réglementaire peut être illustré par la stratégie d'Arco, the world's eighth-ranking oil company. Having developed a major research and development programme starting in 1988, it put out a clean automobile fuel at the end of 1990, tout en s'engageant sur un programme volontaire. This proactive environmental strategy which led it to develop and implement environmental technology innovation that ended up influencing and anticipating environmental regulations (including some 1990 amendments to the Clean Air Act) in order to obtain a competitive edge in the highly competitive oil industry, sans que l'impact bénéfique sur l'environnement soit définitivement démontré (Piasecki 1995).Par ailleurs, dans le cas d'engagements collectifs, certaines firmes, en entretenant le flou sur leur performances 
environnementales réelles peuvent exploiter les gains de l'engagement sans supporter les coûts de la dépollution (le comportement du passager clandestin).

Far from slowing down the setting of standards, deregulation has actually coincided with more and more technical standards being adopted by trade and industry bodies. At the international level, a new generation of ISO standards on environmental management is being drafted. These ISO 14000 standards (especially 14020, 21, 22, 23 and 24; some are still being developed), which contain provisions relating to environmental labelling, in some respects resemble the ISO 9000 standards on quality. Furthermore, national standards are being adopted, as illustrated by the French X 30-200 and the British BS77-50 standards. Environmental standards are also being developed for specific sectors at the initiative of industries. This was the case, for example, with the standard on the environmental properties of electrotechnical products created by the International Electrotechnical Commission (IEC). Cependant, ces dispositifs de certification ou même le système européen "éco-audit" comportent les mêmes risques environnemetaux et sociaux que les outils précédents dans la mesure où là encore les firmes s'engagent volontairement dans des programmes normalisés par une autorité de certification (ou une autorité publique pour "l'éco-audit").

The evolutionary systems view of economic and ecological change that underpins our analysis of "win-win" strategy is exemplified in the work of Krupp (1992). According to him, the economic dynamism is manifest through technological innovation and the incessant release of new and "improved" products. The commodity economy and circuits of capital now become the main engines and beneficiaries of this dynamic of innovation, a positive-feedback loop driven by the quest for profits, and characterised by incessant liquidation and renewal. Yet, the intensification and extensification (through the growth of output and mass consumption levels) of this innovation process now threatens global resources and ecological conditions of life for hundreds of millions of people : fossil-fuel resources are being used up within a few generations in processes which endanger the earth with pollution and global warming; large quantities of radioactive materials are being destabilised into toxic fission products; tropical forests shrink perceptibly each year; pesticides cause problems of drinking-water pollution; and so on... Ce phénomène apparaît comme une "externalisation des coûts" des firmes sur l'Etat, le public au sens large, les générations futures et la nature nonhumaine (Beckenbach, 1994; O'Connor, 1994a). Les firmes compétitives cherchent d'une part les coûts des inputs les plus faibles, d'autre part à répercuter les coûts externes sur les autres acteurs (gouvernements, communautés, générations futures, non humains etc...) lorsque les profits et la survie commerciale sont en jeu. Le conflit entre intérêt privé et coût social devient alors patent.

\subsection{From "win-win" firm strategies to sustainable development}

L'Etat, après avoir reçu implicitement de la communauté qu'il représente, un mandat pour protéger l'environnement, semble délèguer à son tour à l'entreprise la charge de la protection de l'environnement. Ainsi explique t-on la substitution progressive des engagements volontaires aux instruments réglementaires et économiques comme un mécanisme de délégation de l'Etat à la firme que l'on tend à analyser comme une relation Principal-Agent. Or, dans le contexte de complexité et d'incertitude forte des problèmes contemporains d'environnement, les phénomènes d'asymétries d'information se trouvent exacerbés. La conséquence de ces problèmes d'information est d'une part que le contrat qui lie les parties est incomplet, et d'autre part que le principal n'a pas les capacités techniques, organisationelles et financières de contrôler parfaitement et sans coût l'action de l'agent (problèmes d'hasard moral et de sélection adverse). La relation principal-agent repose sur un individualisme méthodologique qui conduit à ramener tout rapport économique à un ensemble de relations inter-individuelles souvent bilatérales et sur un principe hiérarchique entre agents. Or, dans le cadre du développement soutenable, les relations entre les acteurs ne peuvent pas être décrites comme de simples contrats bilatéraux en supposant des positions égales entre les parties, dans la mesure où la reconnaissance de certains acteurs (générations futures, non humains, etc...) n'est pas acquise. 
Dès lors le mécanisme de délégation ne peut pas se réduire à ce formalisme, sous peine d'être qualifié de "coopération faible" (Aggeri, Hatchuel, 1996). Il doit s'étendre à l'ensemble des acteurs de la communauté.

Les institutions nationales et internationales ainsi que les citoyens, doivent jouer un rôle complémentaire à celui des firmes dans le choix des trajectoires technologiques environnementales. Oublier ces autres composantes risque, sur le long terme, de transformer les stratégies "win-win" en stratégies "wrong-wrong", c'est-à-dire en stratégies doublement mauvaises, sur le plan de la compétitivité et sur celui du développement soutenable. Le scandale de juin 1995 autour de la plate-forme de pétrole Brent illustre parfaitement le danger, au niveau même de la compétitivité, de ne pas passer à une "coopération forte" entre tous les "stakeholders" dans les décisions comportant des enjeux environnementaux. Shell avait envisagé de descendre cette plate-forme dans la mer du Nord puisque le gisement pétrolifère était épuisé. Greenpeace organisa une vaste action de protestation, largement suivie par les médias et les citoyens qui boycotèrent les stations service de Shell ce qui leur causa des pertes considérables à la firme et finit par l'abandon du projet (Freese, 1995).

Les firmes sont soumises à une pression verticale provenant de l'opinion publique et de la réglementation via les gouvernements. Elles sont également soumises à une pression horizontale liée aux exigences des donneurs d'ordre, des banques, des assurances et des actionnaires. Les assureurs, par exemple au Canada, commencent à différencier les primes d'assurance contre les risques environnementaux en fonction de l'appartenance à certains engagements volontaires (Programme Responsible Care). Certains actionnaires et certaines banques orientent davantage leurs capitaux en fonction des risques environnementaux et privilégient les firmes faisant preuve d'efforts particuliers dans ce domaine (comme l'industrie minière regroupée au sein de ICME). Cette pression est plus longue à mettre en place mais elle est également plus efficace, car elle affecte directement les ventes des entreprises. Il n'est alors pas nécessaire que les responsables d'entreprise soient eux mêmes convaincus de la nécessité de traiter l'environnement d'une façon stratégique pour être conduits à le faire. Il suffit qu'il leur paraisse vraissemblable que leurs concurrents, les institutions publiques et les citoyens confèrent un tel statut à l'environnement. En situation de forte incertitude sur les conventions environnementales du futur, un élément clé de la coordination économique est l'intervention de partenariats collectifs pour offrir des connaissances et visions du monde communes et de nouvelles normes de comportement ayant un effet de légitimation d'une orientation ou d'une préoccupation donnée. Cette conception est d'ailleurs partagée la Commission Européenne qui, pour préparer sa position lors de la conférence de Kyoto sur le changement climatique en décembre 1997, a développé toute une série de consultations favorisant le dialogue entre la communauté scientifique,des acteurs internes à la Commission et des acteurs externes, dont l'industrie, la finance, les citoyens, les syndicats, les associations de citoyens, les associations de défense de l'environnement, etc...

Certains types d'engagements volontaires, tels les "covenants" néerlandais, même s'ils n'impliquent pas la signature de tierce parties dans le contrat (ONG, groupes verts, associations locales), reposent sur une participation de ces acteurs sous la forme de consultations. De même, en Allemagne, l'importance des acteurs extérieurs, en particulier les associations de défense de l'environnement et les syndicats, se retrouve dans l'organisation de la procédure de validation de l'éco-audit européen, encore qualifié de système Européen de Management de l'Environnement (SEME). Enfin, l'écolabélisation comprend, en général, une phase de négociation entre les pouvoirs publics et les divers goupes d'intérêt afin de définir les critères d'écolabélisation (Nadaï, 1997).

Tenir compte des intérêts divergents des différents "stake-holders" dans un dialogue en temps réel, fournit aujourd'hui une base pour aider les décideurs dans l'évaluation des risques, dans la prioritisation et la révision des actions relevant, notamment du domaine de l'innovation technologique environnementale. Ce processus de consultation permanente et d'échange 
d'informations, reposant sur ce qu'il est courant de qualifier de rationalité procédurale, constitue un véritable outil de gouvernance faisant intervenir un principe de responsabilité élargie qui sort du cadre de la simple relation Principal-Agent .

\section{CONCLUSION}

Evolutionary perspective, with its notions of non-linear feedbacks and multiple criteria, can help to suggest ways that technological futures could be created by environmental radical innovations and sustainable policy choices that come to be amplified in their effects through time on the contemporary industrial dynamics. It promises to be fruitful for Ecological-Economics to integrate the lessons from evolutionary theory on technological change. Indeed one challenge for Ecological Economics is to help to discern technological and institutional choices that are "constructive" in the normative sense of sustainability. The ideals of social as well as economic and ecological sustainability entail pursuit of strategies of solidarity, through a real governance with the participation of the main stakeholders in the technological path decision making in the way of "post-normal science" as defined by Funtowicz and Ravetz (1994). Such a "process of debate and dialogue operating continuously over all phases of a policy process" (Funtowicz \& Ravetz, 1991, p 22) soulignent les limites à la fois de l'Etat libéral et de l'Etat social classiques. Il s'agit d'initier des pratiques de consumltations élargies, de régulation négociée, de certains méthodes de délégation à des autorités indépendantes, de contrôle des technologies et de l'usage accru des mécanismes d'évaluation et d'audit. En effet, le choix et l'accomplissement des objectifs de politiques de développement soutenable dépendent moins de la fermeté de jugement et d'action des instances de régulation que de la manière dont les multiples acteurs se trouvent associés, tant à la préparation des réglementations, qu'à leur mise en application. As the chairman of $A K Z O$, a chemical corporation, recently commented (Schot 1996):

"History shows that no firm has ever outlived a permanent conflict with society. Dialogue, adjustments and co-operation are therefore not luxuries but rather necessities."

\section{ACKNOWLEDGMENTS :}

Ce travail a pu être réalisé grâce aux soutiens de deux recherches en France: (i) pour le Ministère de l'Environnement et de l'Aménagement du Territoire, "Implications de la mondialisation de l'économie sur la relation environnement-entreprises"; et (ii) pour le CNRS, l'ADEME et les Clubs Crin, "Analyse des implications srtatégiques des contraintes et des opportunités environnementales: une comparaison France-Allemagne à partir du secteur cimentier". Certains aspects, notamment sur les stratégies d'entreprise ont également pu être approfondis grâce à une étude pour l'OCDE ("Economic Globalisation, Competitiveness, and Environment", in Globalisation and Environment: Preliminary Perspectives, OECD, Paris, pp 101-41, 1997), à laquelle, en plus des deux auteurs de ce papier, Martin O'Connor avait contribué. 


\section{REFERENCES}

Aggieri, F. and Hatchuel, A., 1996. A Dynamic Model of Environmental Policies. The Case of Innovation Oriented Voluntary Agreements. In: Conference The Economics and Law of Voluntary Approaches in Environmental Policies. 18-19 November at Venice.

Amendola, M., Froeschlé, C., Gaffard, J.L. and Lega, E., 1996. Cyclical Growth and Primary Resource Constraint. In: S. Faucheux, D. Pearce, J. Proops (eds). Models of Sustainable Development. Cheltenham, E.Elgar, pp 176-187

Aoki, M., 1986. Horizontal vs. Vertical Information Structures of the Firm. American Economic Review, 76: $971-83$

Aoki, M., 1990. Towards an Economic Theory of the Japanese Firm. Journal of Economic Litterature, 26 (1).

Bain, J., Barriers to new competition, Harvard University Press, Cambridge, Massachusets, 1956.

Beckenbach, F., 1994. Social Costs in Modern Capitalism. In: M. O’Connor (ed.), Is Capitalism Sustainable?. Guilford Publications, New York, pp.91-105.

Beckenbach, F., 1998. Socio-Technological Innovation and Sustainability. In: S. Faucheux, J. Gowdy and I. Nicolaï (eds). Sustainability and Firms : Technological Change and the Changing Regulatory Environment. Edward Elgar, Cheltenham, UK and Brookfield, US (forthcoming).

Benhaïm, J. and Schembri, P., 1996. Technical Change: an Essential Variable in the Choice of a Sustainable Development Trajectory. In: S. Faucheux, D.W. Pearce and J.L.R. Proops (eds), Models of Sustainable Development. Edward Elgar, Cheltenham, UK and Brookfield, US.

Borkey, P. and Glachant, M., 1997. Les engagements volontaires de l'industrie dans le domaine de l'environnement : nature et diversité. In: Rapport CERNA, ADEME et Ministère de l'Environnement, France, Juin.

Chailloux, N., 1996. Implications de la Mondialisation de l'Economie sur la Relation EnvironnementEntreprise. In: Rapport C3ED sous la direction de S. Faucheux. Ministère de l'Environnement, France, Janvier

Chandler, A.D., 1977. The Visible Hand : the Managerial Revolution in American Business. University Press Cambridge.

Daly, H., 1991. Steady State Economics, Island Press, Washington D.D.

De Marchi, B., 1997. Seveso: from pollution to regulation. International Journal of Environment and Pollution, 7(4): 526-538.

DG III, 1995. Attitude and Strategy of Business Regarding Protection of the Environment, Common Environmental Framework. European Commission DG III. November.

Duchin, F., Lange, G.M. and Kell, G., 1995. Technological Change, Trade, and the Environment. Ecological Economics, 14: 185-193.

Faucheux, S., 1997. Technological Change, Ecological Sustainability and Industrial Competitiveness. In: A.K Dragun and K.M. Jacobsson (eds). Sustainability and Global Environmental Policy: New Perspectives. Edward Elgar, Cheltenham, UK and Brookfield, US, pp. 131-148

Faucheux, S., Muir, E. and O'Connor, M., 1997. Neoclassical theory of natural capital and 'weak' indicators for sustainability. Land Economics, November (forthcoming)

Faucheux, S., Nicolaï, I. and O'Connor, M., 1997. Economic Globalisation, Competitiveness, and Environment. In: OECD (ed.), Globalisation and Environment. OECD, Paris.

Faucheux, S. and Noël, J.F., 1995. L'économie de l'environnement et des ressources naturelles. Armand Colin, Paris 
Faucheux; S. and O'Connor, M. (eds), 1997. Valuation for Sustainable Development: Methods and policy indicators. Edward Elgar, Cheltenham, UK and Brookfield, US (forthcoming).

Freeman, C., 1982. The Economics of Industrial Innovation. Pinter, London.

\section{Freese voir dans le mémoire de JULIA HAAKE (tu as du le garder)}

Frosh, R.A., 1995. Industrial Ecology, Adaptating Technology for a Sustainable World. Environment, December: 16-24 and 34-37.

Funtowicz, S.O and Ravetz, J., 1991. A new scientific methodology for global environmental issues. In: R. Costanza (ed.). Ecological Economics: The Science and Management of Sustainability. Columbia University Press, New York, pp 137-152.

Funtowicz, S.O and Ravetz, J., 1994, The worth of a songbird: Ecological Economics as Post-Normal Science. Ecological Economics, 10: 197-207.

Gastaldo, S. and Ragot, L., 1996. Sustainable development through endogenous growth models. In: S. Faucheux, D. Pearce and J. Proops (eds). Models of Sustainable Development. Edward Elgar Cheltenham, UK and Brookfield, US, pp 73-87.

Gramond, V. et Setbon, V., 1996. Analyse des Implications Stratégiques des Contraintes et Opportunités Environnementales: une Comparaison France-Allemagne à partir d'une Etude du Secteur Ciment. Rapport sous la direction de S.Faucheux. Programme Environnement, Société, Entreprise: la Nouvelle Donne, France, Octobre.

Haake, J. and Hinterberger, F., 1997. Economic and Ecological Aspects of Products Durability. In: U. Ganslosser and M. O'Connor (eds). Ecology Society Economy : Life Sciences Dimensions. Filander Press.

Krupp, H., 1992. Energy Politics and Schumpeter Dynamics: Japan's Policy Between short-Term Wealth and Long-Term Global Welfare. Springer-Verlag, Tokyo, 394 pp.

Malaman, R., 1998. After the Age of Abatement Technologies? Technological Change for Sustainable Development. In: S. Faucheux, J. Gowdy and I. Nicolaï (eds). Sustainability and Firms : Technological Change and the Changing Regulatory Environment. E.Elgar, Cheltenham, UK and Brookfield, US, (forthcoming).

Miller, A. and Moore, C., 1994. Strengths and Limitation of Governmental Support for Environmental Technology in Japan. Industrial and Environmental Crisis Quarterly, 8 (2): 155-170.

Ministry of International Trade and Industry (MITI), 1988. White Paper on Industrial Technology: Trends and Future Tasks in Japanese Industrial Technology. MITI, Tokyo.

Moreau, F., 1994. L'Entreprise face aux Diverses Formes du Risque Environnemental. Revue d'Economie Régionale et Urbaine, 4: 668-680.

Nadaï, A., 1997. Concurrence sur la qualification environnementale des produits. Communication au colloque "Dynamiques industrielles et contraintes environnementales", 12-13 Mai, Nice-Sophia Antipolis.

Nordhaus, W.D., 1992. Is Growth Sustainable? Reflections of the concept of sustainable economic growth. Paper for International Economic Association, October at Varenna.

Norgaard, R.B., 1994. Development Betrayed. The end of progress and a coevolutionary revisioning of the future. Routledge.

O'Connor, M. (ed.), 1994a. Is Capitalism Sustainable?, Guilford Publications, New York.

O'Connor, M., 1994b. The Material/Communal Conditions of Production. Capitalism Nature Socialism 5(3): 95-104.

Palmer, K., Oates, W.E. and Portney P.R., 1995. Tightening Environmental Standards: The Benefit-Cost or the No-Cost Paradigm. Journal of Economic Perspectives, 9 (4): 119-132. 
Piasecki, B.W., 1995. Corporate Environmental Strategy - The Avalanche of Change since Bhopal. J. Wiley \& Sons, New York.

Porter, M.E. and Linde van der C, 1995. Toward a New Conception of the Environment-Competitiveness Relationship. Journal of Economic Perpectives, 9 (4): 97-118.

Porter, M.E., 1990. The Competitive Advantage of Nations, NY Free Press.

Ropke, I., 1996. Technology optimism in a socio-economic perspective. Journal of Income Ditribution, 6.

Saviotti, P., 1986. Systems theory and technological change. Futures, 18: 773-86.

Schot, J., 1996. Facing the Sustainable Challenge; Strategic Choices for Industrial Firms. Public lecture in Paris Conference, march 25.

Setbon, V., 1997. Waste incineration in cement plants: contraints and development opportunities (a French-German comparison). International Journal of Environment and Pollution, 7 (4): 547-560.

Shrivastava, P., 1995, Democratic Control of Technological Risks in Developing Countries. Ecological Economics, 14: 195-208.

Skea, J., 1994. Environmental Issues and Innovation. In: Dodgson M., Rothwell R. (eds.). Handbook of Industrial Innovation, E.Elgar, Cheltenham, UK and Brookfield, US, pp.421-431.

Stiglitz, J.E, 1974. Growth with exhaustible natural resources: Efficient and optimal growth paths. Review of Economic Studies, 41: 123-137. 